\title{
The relation between survival and expression of HERI and HER2 depends on the expression of HER3 and HER4: a study in bladder cancer patients
}

\author{
AA Memon",', BS Sorensen', P Meldgaard ${ }^{2}$, L Fokdal ${ }^{1,2,3}$, T Thykjaer $^{3}$ and E Nexo' \\ 'Department of Clinical Biochemistry, NBG, AS, Aarhus University Hospital, 8000 Aarhus C, Norrebrogade 44, Denmark; ${ }^{2}$ Department of Oncology, \\ NBG, AS, Aarhus University Hospital, Norrebrogade 44, 8000 Aarhus C, Denmark; ${ }^{3}$ Department of Clinical Biochemistry, Skejby Hospital, 8200 Aarhus \\ N, Norrebrogade 44, Denmark
}

\begin{abstract}
Increased expression of the epidermal growth factor (EGF) receptors, HERI and HER2 are related to poor prognosis in most cancers studied. Recently, a high expression of the two remaining receptors of the EGF system, HER3 and HER4 has been related to a favourable prognosis. However, prognostic significance of HERI and HER2 receptors in bladder cancer is controversial and the effect of the expression of different combinations of these receptors on patient survival is not well understood. Therefore, we examined the mRNA expression of all four EGF receptors with real-time polymerase chain reaction in biopsies from 88 patients with bladder cancer, where the survival was followed for a median of 38.5 months (range I - I 17 months). Expression of HERI and HER2 alone showed no correlation with survival. However, a high expression of HERI together with high expression of HER3 and HER4 correlated to a better prognosis compared to the high expression of HERI together with low expression of HER3 and HER4 $(P=0.0006)$. Also, a significantly longer survival was observed in patients expressing high HER2 when coexpressed with high HER3 and HER4, as compared to the survival in patients with tumours expressing high HER2 but low HER3 and HER4 $(P=0.0005)$. Our results suggest that the final outcome of patients with high HERI - and HER2-expressing tumours depends on the expression of HER3 and HER4.

British Journal of Cancer (2006) 94, 1703-1709. doi:I0.1038/sj.bjc.6603154 www.bjcancer.com

Published online 9 May 2006

(C) 2006 Cancer Research UK
\end{abstract}

Keywords: ErbB; HER; EGFR; epidermal growth factor; bladder cancer

The epidermal growth factor (EGF) family of receptor tyrosine kinases comprises four members: HER1 (EGF receptor 1 Human EGF Receptor/ErbB1), HER2 (neu/ErbB2), HER3 (ErbB3) and HER4 (ErbB4) (Yarden and Sliwkowski, 2001). Epidermal growth factor receptors are commonly active in a dimeric form and interaction between different EGF receptor pairs represents a mechanism for signal diversification and amplification (Olayioye et al, 2000; Yarden and Sliwkowski, 2001). Various dimeric pairs depend on the concentration of receptors, the concentration of particular ligands and the affinity of the receptors towards each other (Pinkas-Kramarski et al, 1996; Tzahar et al, 1997). Ligands binding the EGF family receptors induce receptor homo- or heterodimerisation, which involves an array of a number of homodimeric and heterodimeric combinations (Burden and Yarden, 1997). The ligands for these receptors consist of approximately 20 different proteins (including isoforms) encoded by at least 10 different genes. The numerous EGF family-specific ligands include EGF and five other ligands able to bind to HER1. Whereas heregulins are the ligands for HER3 and HER4. No ligand for HER2 has been identified and HER3 lacks intrinsic tyrosine kinase activity (Guy et al, 1994). Thus, the normal mechanism by

*Correspondence: Dr AA Memon; E-mail: amemo@as.aaa.dk Revised I 4 March 2006; accepted 5 April 2006; published online 9 May 2006 which HER2 or HER3 can signal is through heterodimerisation with other EGF receptors.

Epidermal growth factor receptors, particularly HER1 and HER2, are commonly deregulated in certain forms of human cancer including bladder cancer. It has been shown that HER 1 and HER2 expressions are involved in poor prognosis (Garcia et al, 2003; Nielsen et al, 2004; Tovey et al, 2004). Despite the numerous studies devoted to the issue of clinical significance of HER1 and HER2, the role of these receptors is still controversial in bladder cancer.

The role of the HER3 and HER4 receptors is not well understood. However, growing consensus has emerged about the role of HER4, and the few clinical studies carried out so far have suggested that its expression is associated with favourable prognosis (Thybusch-Bernhardt et al, 2001; Suo et al, 2002; Rotterud et al, 2005). We have shown that HER3 and HER4 expression correlated with a better prognosis in bladder cancer patients (Memon et al, 2004). More recent reports also suggest that unlike HER1 and HER2, expression of HER3 and HER4 was not found in more aggressive metastatic squamous cell carcinomas of the oral cavity (Ekberg et al, 2005). The same was reported in meningiomas (Andersson et al, 2004). In addition, presence of HER4 in HER2-expressing tumours reduced the recurrence in breast cancer patients, further supporting the distinct roles for EGF family receptors (Barnes et al, 2005). 
It has been demonstrated that EGF receptor heterodimers are more potent in signal transduction than homodimers. Heterodimers provide additional phosphotyrosine residues for the recruitment of effector proteins, and induce distinct patterns of receptor phosphrylation and downstream signalling. This suggests that the outcome of activation of the EGF system depends on the interaction between the EGF receptors.

The prognostic significance of all four receptors in different combinations remains unclear. Knowledge about this is important in order to design the best cancer treatment directed towards these receptors. Today, drugs directed towards HER1 (e.g. iressa/ gefitinib) and HER2 (e.g. trastuzumab) (Diermeier et al, 2005) are already in clinical use and strategies involving inhibition of all four receptors are under evaluation. Therefore, it is important that all four EGF receptors should be analysed in the same group of patients before drawing any conclusion about the prognostic significance of these receptors. Lack to do so could be one of the reasons for the conflicting data about the role of HER1 and HER2 as prognostic markers.

Epidermal growth factor family gene expression can reliably be studied at the mRNA level and based on a number of studies, the expression is likely to reflect the presence of the corresponding protein (Knowlden et al, 1998; Walker and Dearing, 1999; Suo et al, 2002; Junttila et al, 2003).

The present study was undertaken in order to examine the pattern of expression of HER 1-4 in bladder cancer biopsies from 88 patients in relation to survival of the patients. We report that a high expression of HER3 and/or HER4 protects the patients from the consequences of a high expression of HER1 and/or HER2.

\section{MATERIALS AND METHODS}

\section{Patients}

Eighty-eight patients with primary bladder cancer were included. Biopsies were obtained by transurethral tumour resection and alliqotes were frozen immediately. Samples for histological examination were removed before freezing and analysed independent of the further analysis of RNA. Tumour stage was assigned

Table I Clinical data in 88 bladder cancer patients

\begin{tabular}{ll}
\hline Variables & No. of patients \\
\hline Sex & \\
Male & 69 \\
Female & 19 \\
Age (years) & \\
Median & 72 \\
Range & $53-88$ \\
Stage & \\
Ta & 21 \\
TI & 18 \\
T2-T4 & 49 \\
Grade & \\
I/II & \\
III/IV & 26 \\
& 62 \\
Tumour type & \\
Papillary & \\
Solid & 38 \\
Mixed & 37 \\
Tumour size (cm) & 13 \\
$<3$ & \\
$>3$ & 50 \\
\hline
\end{tabular}

according to the Union Internationale Contre le Cancer TumourNode-Metastasis system (Spiessl et al, 2003). Grading was performed in accordance with methods described by Bergkvist et al (1965). The relationship between the distribution of tumour stage, age and sex is summarised in Table 1 . At the time of inclusion, 18 patients had received treatment in the form of radical radiotherapy, chemotherapy or intravesical therapy with bacillus Calmette-Guerin. The follow-up period was from the date of biopsy to the day of death or to July 2005. Patients were censored if they were alive at the time of analysis (July 2005). The median follow-up was 38.5 months (range 1-117 months). The regional committee of Scientific Ethics, Aarhus approved the study, and the procedures were followed in accordance with the Helsinki Declaration.

\section{Preparation of total RNA}

RNA preparation was performed as described before (Memon et al, 2004). Briefly, tumour samples were immediately placed in a denaturing solution $\left(4 \mathrm{moll}^{-1}\right.$ guanidine thiocyanate, $25 \mathrm{mmoll}^{-1}$ sodium citrates (PH7), $0.5 \%$ sarkosyl and $0.1 \mathrm{mmoll}^{-1}$ 2mercaptoethanol) and stored at $-80^{\circ} \mathrm{C}$. A frozen biopsy $(<20 \mathrm{mg}$ ) was homogenised by a Heidolph Diax 600 mixer. Total RNA was extracted from tissues according to a slightly modified method of Chomczynski and Sacchi (1987).

\section{Real-time reverse transcription-polymerase chain reaction quantification of $\mathrm{mRNA}$}

Quantification of mRNA was performed by real-time reverse transcription-polymerase chain reaction on the Lightcycler instrument (Roche, Germany) as described before (Memon et al, 2004). Briefly, cDNA was generated in a reverse transcription reaction, where $1 \mu \mathrm{g}$ RNA was mixed with 2.5 units AMW reverse transcriptase (Applied Biosytems, Foster city, USA) in a reaction mixture containing $10 \mathrm{~mm}$ Tris- $\mathrm{HCl}(\mathrm{pH} 8.3), 1 \mathrm{U}^{-1} \mathrm{l}^{-1}$ RNase inhibitor, $1 \mathrm{mmoll}^{-1}$ deoxyribonucleoside triphosphate (dATP, dTTP, dGTP and dCTP), $2.5 \mu \mathrm{moll}^{-1} 16 \mathrm{mer} \mathrm{d}(\mathrm{T})_{16}$ primer, $50 \mathrm{mmoll}^{-1} \mathrm{KCl}, 6.25 \mathrm{mmoll}^{-1} \mathrm{MgCl}_{2}$ in a total volume of $20 \mu \mathrm{l}$ (all reagents from Applied Biosystem). The reactions were incubated in a perkin Elmer 9700 thermocycler for $90 \mathrm{~s}$ at $94^{\circ} \mathrm{C}$ followed by $30 \mathrm{~min}$ at $42^{\circ} \mathrm{C}$ and finally at $94^{\circ} \mathrm{C}$ for $1 \mathrm{~min}$. Real-time polymerase chain reaction (PCR) was performed with the Lightcycler Sybr Green I quantification kit (Roche) in a total volume of $10 \mu \mathrm{l}$ in LC glass capillaries (Roche). The HER1 primers: $5^{\prime}$ AGAGGAGAACTGCCAGAA-3' (sense) and $5^{\prime}$-GTAGCATTTATG GAGAGTG-3' (antisense); HER2 primers: 5'-CCAGGACCTGCT GAACTGGT-3' (sense) and 5'-GTACGAGCCGCACATCC-3' (antisense) give rise to a 454 and $272 \mathrm{bp}$ PCR product, respectively. HER3 and HER4 quantifications were previously determined by same method by amplifying a 365 and $265 \mathrm{bp}$ fragment, respectively (Memon et al, 2004). Beta-actin mRNA was used as an endogenous RNA control, which has been used as control gene in various studies on bladder cancer (Vageli et al, 1996; Chiu et al, 2002) as well as on breast cancer (Agudo et al, 2004). Specificity was verified by the size of the PCR product on agarose gel electrophoresis and nucleotide sequencing using a 310 genetic analyser (Applied Biosystems). A calibration curve and positive and negative controls were included in each run. The results are presented based on a calibration curve of mRNA. The calibration curve was composed of serial dilutions of a pool of mRNA isolated from; HCV cells for measurement of HER1 and HER2 whereas HEC and KLE cells were used for HER3 and HER4, respectively. Likewise, actin mRNA was analysed in the same samples employing mRNA isolated from HCV as calibrator. All the quantifications in this study are presented as ratio between the target gene and beta-actin. Quantifications were performed using Lighcycler Software Version 3 (Roche). 


\section{Statistical analysis}

Nonparametric tests were used throughout this study. Two-sided $P$-values $<0.05$ were considered to be significant. The $\chi^{2}$ test was used to compare the expression of the EGF family members with clinical stage, grade, tumour type and size of the tumour. Life table calculations were carried out using the Kaplan-Meier method. Comparison between the curves was carried out using log-rank test. (The software Graph Pad Prism (version 4) was used for statistical analysis.)

\section{RESULTS}

Pattern of EGF family receptor expression and correlation with histopathological parameters of bladder cancer

We report the mRNA expression of HER1 and HER2 in bladder cancer biopsies from 88 patients followed for a median of 38.5 months (range 1-117 months). HER3 and HER4 mRNA expressions have previously been determined on the same samples (Memon et al, 2004). HER1 was expressed in $96 \%$ ( 85 out of 88

Table 2 Correlation between combinations of HERI and HER3/HER4 and clinicopathological parameters of bladder cancer

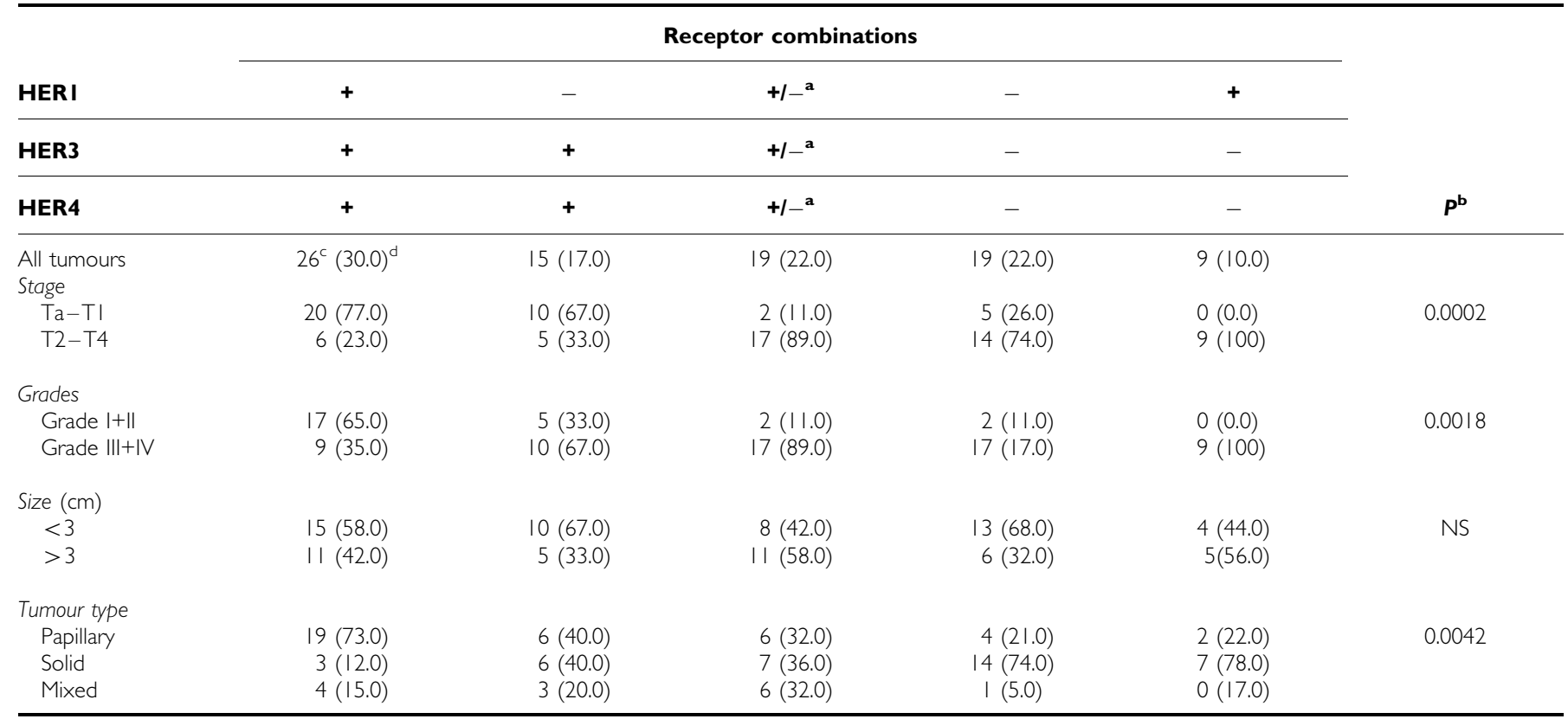

NS = not significant. ${ }^{a}$ Both high and low HERI tumours expressing either high HER3 or high HER4. ${ }^{b} \chi^{2}$ test, analysis was performed between combinations of $+\mathrm{HER} / /+\mathrm{HER} 3 /$ +HER4, +HER3/+HER4 and +HERI only expressing tumours. 'No. of patients. dPercentage.

Table 3 Correlation between combinations of HER2 and HER3/HER4 and clinicopathological parameters of bladder cancer

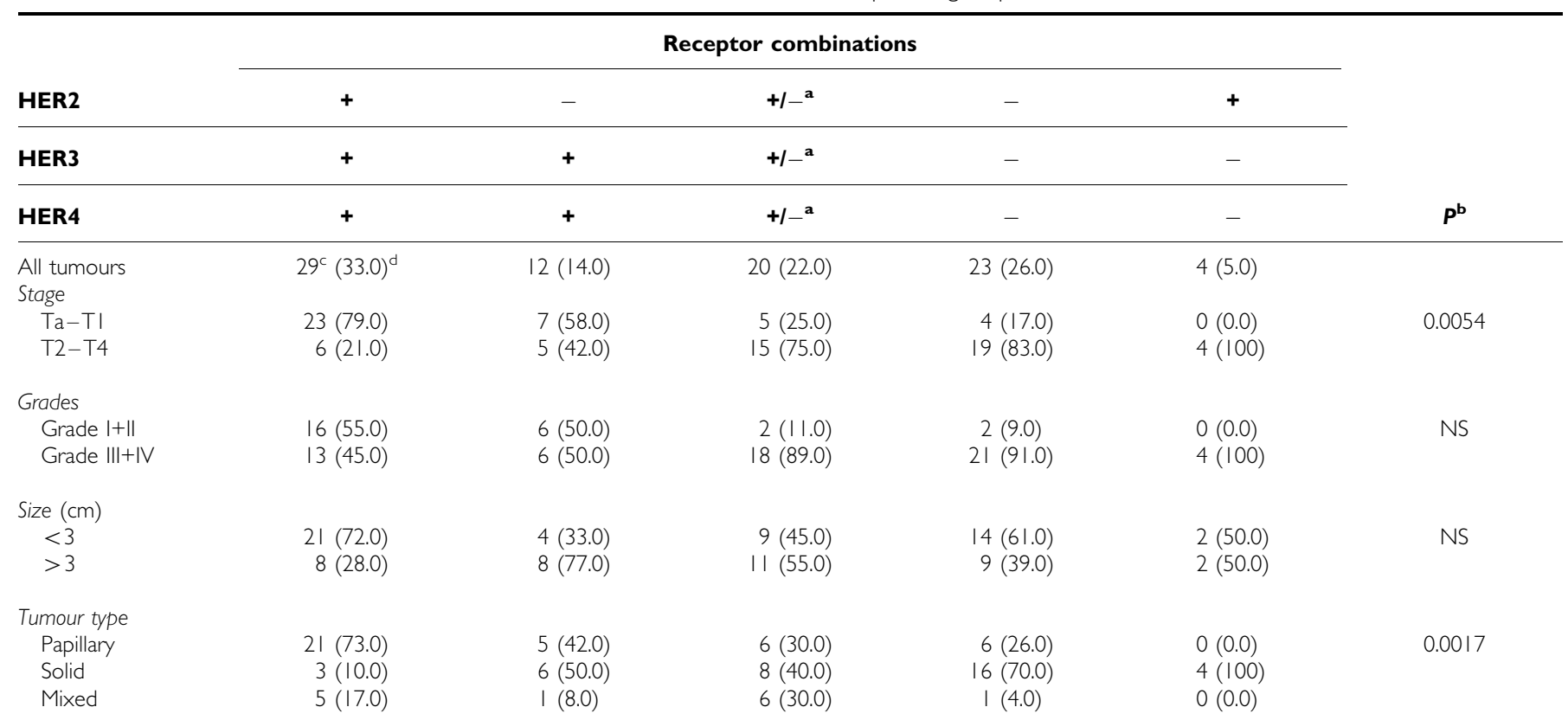

$\mathrm{NS}=$ not significant. ${ }^{a}$ Both high and low HER2 tumours expressing either high HER3 or high HER4. ${ }^{b} \chi^{2}$ test, analysis was performed between combinations of $+\mathrm{HER} 2 /+\mathrm{HER} 3 /$

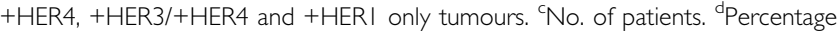


patients) and HER2 in $98 \%$ (86 out of 88 patients) of the tumour samples. As previously reported (Memon et al, 2004), HER3 and HER4 expressions were found in 99 ( 87 out of 88 patients) and $63 \%$ (56 out of 88 patients) of the tumour samples, respectively. Median concentrations of each mRNA examined were selected as the cutoff point, dividing all patients into two groups, one with high expression (above median, denoted as $(+)$ ) and another with low expression (at or below median, denoted as $(-)$ ). High expressions of HER1 or HER2 when coexpressed with high HER3 and HER4 strongly correlated $(P<0.05)$ with good prognostic indicators of bladder cancer (early stage of tumour (Ta-T1), low grade (Grade I/II) and papillary type of tumour). In contrast, tumours expressing only high HER1 or HER2 but low HER3 or
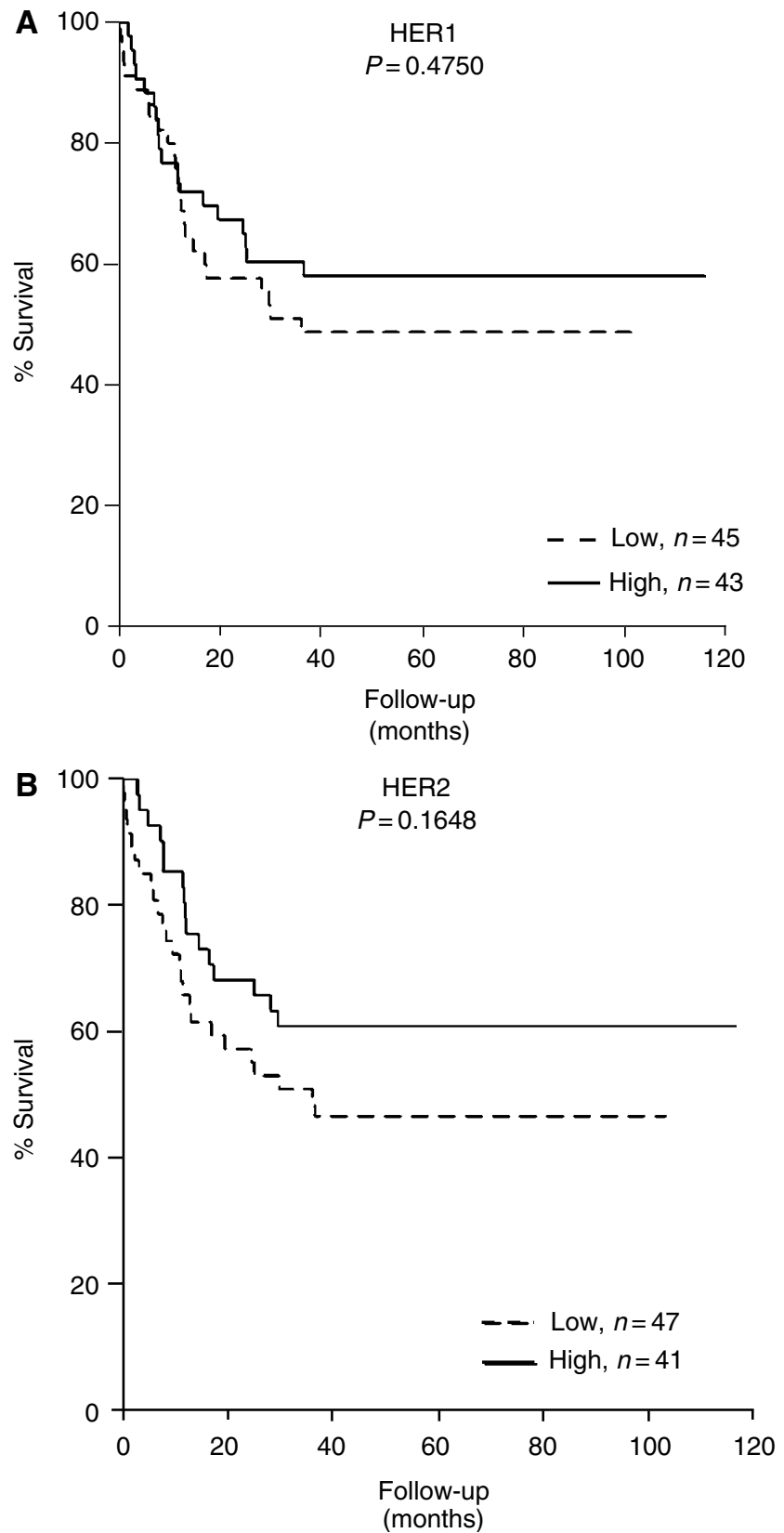

Figure I Kaplan-Meier overall survival analysis comparing patients with high (above median) and low (below median) HERI (A) or HER2 (B) individual expression in 88 bladder cancer patients. $P$-value represents logrank differences in survival between two groups.
HER4 correlated with poor prognostic parameters of bladder cancer (late stage of tumour (T2-T4), high-grade (Grade III/IV) and solid type of tumour). In relation to stages of the tumour, 77 and $79 \%$ of the patients coexpressing high levels of HER1, HER3 and HER4 ( + HER1/ + HER3/ + HER4) (Table 2) or high levels of HER2, HER3 and HER4 (+ HER2/ + HER3/ + HER4) (Table 3), respectively, correlated with early stage of the tumour $(\mathrm{Ta}-\mathrm{T} 1)$. Whereas, $100 \%$ of tumours overexpressing HER 1 or HER 2 with low expression of HER3 and HER4 (+ HER1/-HER3/-HER4) and (+ HER2/-HER3/-HER4) correlated with late stage (T2-T4) of the bladder cancer.

\section{Correlation with survival}

The median mRNA concentrations of each EGF receptors in all the bladder tumours were selected as the cutoff limit and patients were categorized into groups with high (above median) or low expression (below median). Kaplan-Meier survival curves were made to evaluate the impact of expression of HER1 and HER2 individually and in combination with HER3 and HER4. Patients were divided into the following groups. Group (a) patients expressing high HER1, HER3 and HER4, (b) patients expressing low HER1 with high HER3 and HER4, (c) patients expressing low all four receptors and (e) patients expressing high HER1 with low HER3 and HER4. There was a group of patients expressing high HER1 together with a high expression of either HER3 or HER4 and another group of patients expressing low HER1 together with a high expression of either HER3 or HER4, both groups were combined and shown as (d). The same grouping was performed for the HER2, HER 3 and HER 4 combinations (Figures 1 and 2 present, legend tables).

Expression of either HER1 or HER2 (Figures 1A and B) or these two receptors in combination (data not shown) did not correlate with survival $(P>0.05)$. However, patients having tumours expressing high HER1 together with high expressions of HER3 and HER4 had a better survival (Figure 2A) compared to the patients expressing high HER1 but low expression of HER3 and HER4 $(P=0.0006)$ (Figure 2A, compare a with e). Also patients having tumours expressing high HER2 together with high expressions of HER3 and HER4 had a better survival (Figure 2B) than did the patients expressing high HER2 but low HER3 and HER4 $(P=0.0005)$ (Figure $2 \mathrm{~B}$, compare a with e). It was also observed that the presence of high expression of either HER1 or HER2 did not affect the survival of high HER3- and HER4expressing tumours $(P>0.05)$. Patients with high HER3 and HER4 expression irrespective of the presence of high or low HER1 (Figure 2A, compare a and b) or HER2 (Figure 2B, compare a and b) showed comparable and favourable survival.

We also analysed the effect of high expression of HER3 (irrespective of the expression of HER4) together with high expression of HER1 or HER2. Likewise, the effect of high HER4 (irrespective of the HER3 expression) in combination with high expression of HER1 or HER2 was analysed. Our results showed that high expression of HER3 together with high HER1 or HER2 expression also correlated to better survival (data not shown). Similarly, high expression of HER4 together with high HER1 or HER2 expression also correlated to better survival (data not shown). However, the effect was less marked than observed for tumours where both HER3 and HER4 were coexpressed at a high level together with HER1 or HER2.

We also analysed the relation between survival and HER3 and HER4 expressions in the subgroup of patients with invasive tumours (T1-T4). Our results show that expression of high HER3 and HER 4 compared to low HER3 and HER4 correlated with better prognosis even in this highly invasive group of tumours (Figure $3 \mathrm{~A}$ ). In addition, we also analysed the survival function of HER 3 and HER4 in the group of patients with solid and mixed type of tumours. In this group, we also found a trend showing that 

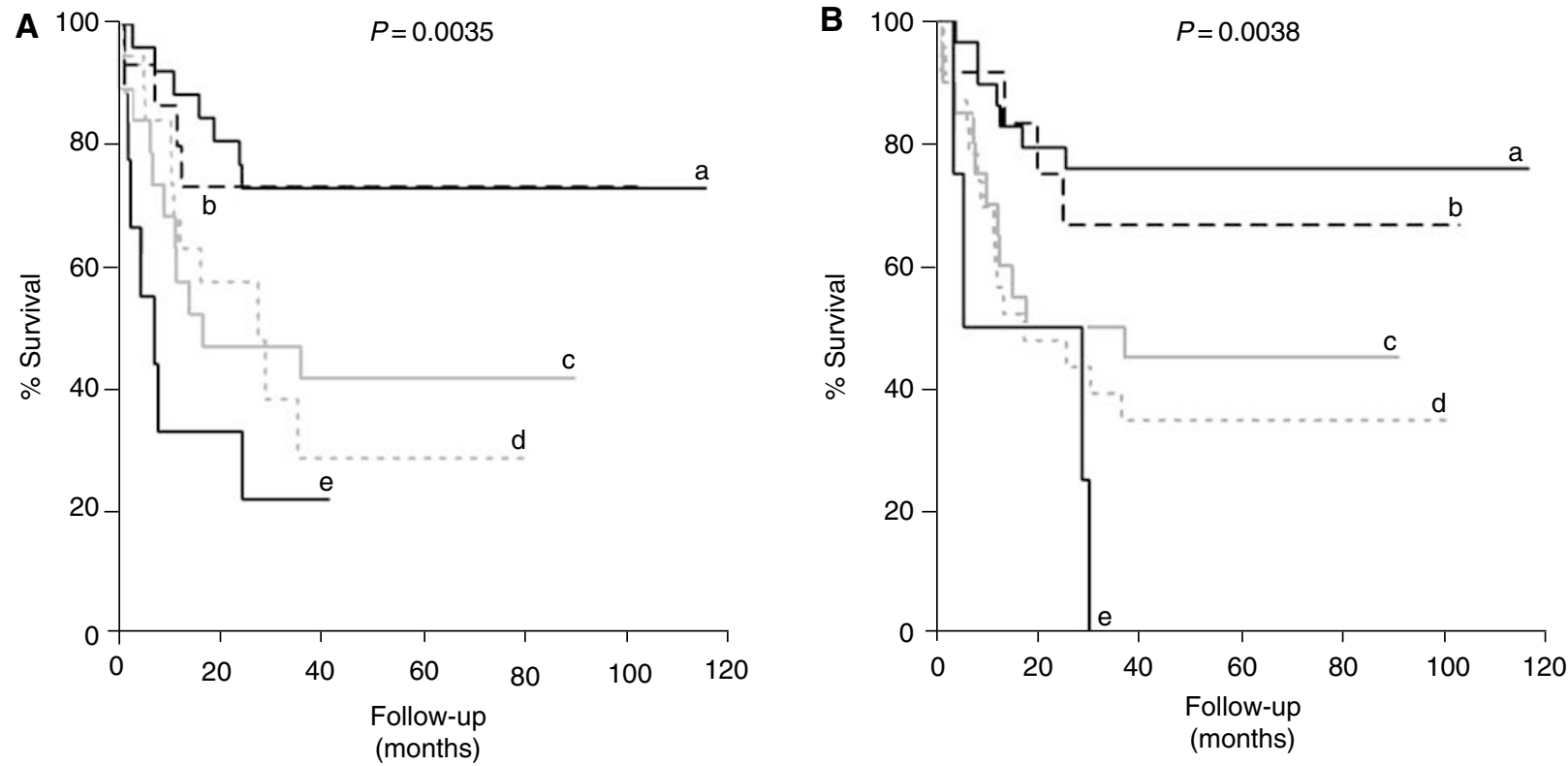

\begin{tabular}{|c|c|c|c|c|}
\hline Legend & HER1 & HER3 & HER4 & $\begin{array}{c}\text { Patients } \\
\text { no. }\end{array}$ \\
\hline a & + & + & + & 26 \\
\hline b & - & + & + & 15 \\
\hline c & $+/-1$ & \multicolumn{2}{|c|}{$+^{1}$} & 19 \\
\hline d & - & - & - & 19 \\
\hline e & + & - & - & 9 \\
\hline
\end{tabular}

${ }^{1}$ Both HER1 high and low tumours, expressing either high HER3 or HER4

\begin{tabular}{|c|c|c|c|c|}
\hline Legend & HER2 & HER3 & HER4 & $\begin{array}{c}\text { Patients } \\
\text { no. }\end{array}$ \\
\hline $\mathrm{a}$ & + & + & + & 29 \\
\hline $\mathrm{b}$ & - & + & + & 12 \\
\hline $\mathrm{c}$ & $+/-1$ & \multicolumn{2}{|c|}{$+{ }^{1}$} & 20 \\
\hline $\mathrm{d}$ & - & - & - & 23 \\
\hline $\mathrm{e}$ & + & - & - & 4 \\
\hline
\end{tabular}

${ }^{1}$ Both HER2 high and low tumours, expressing either high HER3 or HER4

Figure 2 Kaplan-Meier survival curves demonstrating survival function of all EGF receptors in various combinations in 88 bladder cancer patients. HER I (A) or HER2 (B) expressing tumours correlated to worst prognosis in the absence of both HER3 and HER4 expressions. Legend tables showing various combinations analysed. P-value represents log-rank difference in survival between all groups.

patients expressing high HER3 and HER4 had a better survival compared to the patients expressing low HER3 and HER4 (Figure 3B).

Finally, we examined whether treatment of patients before biopsies were taken, had any effect on our final conclusions, but we did not find this to be the case (data not shown).

\section{DISCUSSION}

The EGF family receptors and its ligands are involved in cancer development and prognosis. Abnormal function of the members of the EGF family has been linked to bladder cancer prognosis. Several reports, based mainly on the expression of HER1 and HER2, demonstrate that the EGF family of receptors are involved in poor prognosis in various cancers including bladder cancer (Lonn et al, 1995; Arpino et al, 2004; Blackwell et al, 2004; Popov et al, 2004). In contrast to HER1 and HER2, our study on bladder tumours (Memon et al, 2004) and other studies on breast tumours (Abd El-Rehim et al, 2004) have suggested that increased expression of HER3 and HER4 is associated with improved survival. This is supported by data on cancer cells that demonstrate a ligand-dependent proapoptotic function of the HER4-expressing cells (Sartor et al, 2001). Furthermore, recent findings about HER4 expression in breast tumours also point towards a proapoptotic function of HER4 (Barnes et al, 2005). These studies demonstrate that different EGF receptors function differently, and that the expression pattern of the individual receptors may be of importance in determining the cellular outcome. However, very limited information is available where the expression of all four receptors has been analysed and related to the survival of bladder cancer patients.

Our results show that neither individual nor combined expression of HER1 and HER2 correlated with survival, in agreement with some of the previous reports on bladder cancer (Jimenez et al, 2001; Thogersen et al, 2001). However, conflicting reports have been published on the prognostic value of HER1 and HER2 receptors in bladder cancer. For example, HER1 and HER2 expressions were correlated with both good (Gandour-Edwards et al, 2002; Chakravarti et al, 2005) and poor (Kruger et al, 2002; Popov et al, 2004) prognosis in bladder cancer, whereas other suggest that there is either no or only limited prognostic significance of HER1 and HER2 expression in this disease (Mellon et al, 1996; Ravery et al, 1997).

In vitro studies suggest that cell lines expressing only one of the HER receptors were unable to form tumours in animals with the exception of HER1, which was weakly tumorigenic. Moreover, although unable to form tumours when expressed alone, HER2 was 

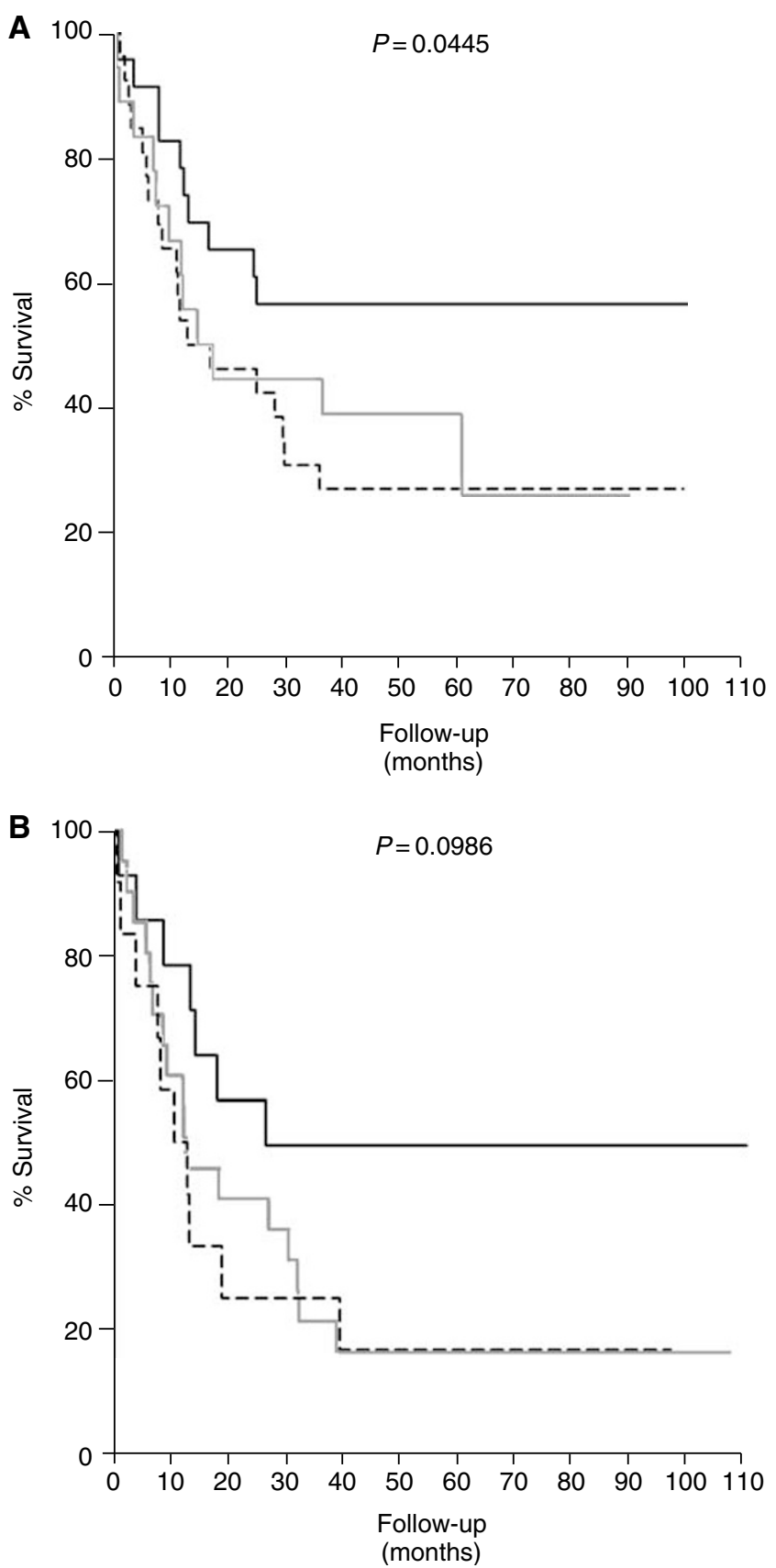

Figure 3 Kaplan-Meier curves showing survival analysis of coexpression of HER3 and HER4 in $(\mathbf{A})$ patients with TI-T4 tumours $(n=67)$ and $(\mathbf{B})$ patients with solid and mixed type of bladder cancer $(n=50)$. All patients were divided into three groups according to HER3 and HER4 coexpressions. Black line denotes patients with high HER3 and HER4 expressions $(n=23)$, grey line denotes patients with low HER3 and HER4 expressions $(n=26)$ and broken line denotes patients expressing either HER3 or HER4. P-value denotes log-rank differences in survival between high and low HER3 and HER4 expression. tumorigenic when expressed with HER1 or HER3, but not HER4. Of all combinations analysed, cells expressing both HER1 and HER2 were the most aggressive (Cohen et al, 1996). In addition, when HER2-expressing cells were transfected with HER4, antiproliferative and differentiation responses were observed (Sartor et al, 2001), suggesting that HER4 signalling has an opposite effect than HER2 signalling.

Based on these observations, we hypothesised that the final outcome of the bladder cancer patients may depend on the balance between the expressions of EGF receptors.

We demonstrate that a high expression of either HER1 or HER2 has no effect on survival when HER3 and HER4 are present. In contrast, high expressions of either HER1 or HER2, in tumours where HER3 and HER4 are low, result in significantly reduced survival. In our group of patients, we observed that 12 patients were expressing high concentrations of HER1 or HER2 with low HER 3 and HER4, and 10 of these patients died during the course of follow-up ( 8 months median follow-up). In contrary, 34 patients expressing high HER1 or HER2 together with high HER3 and HER4 correlated with longer survival (44 months median followup), and only 10 out of 34 patients died during the follow-up period. This suggests that expression of HER1 and HER2 is involved in tumour progression and poor prognosis in the bladder tumours only when HER3 and HER4 are low. In keeping with our results, studies on breast cancer investigating the expression of the individual EGF receptors also show that increased HER3 and HER4 expression appears to be associated with better prognosis (Quinn et al, 1994; Knowlden et al, 1998). However, it should be noted that in another study, only HER4 was found to be associated with a better prognosis whereas HER1, HER2 and HER3 overexpression was associated with a poor outcome (Witton et al, 2003).

In this study, we are able to show that HER3 and HER4 expression can influence the effect of HER1 and HER2 on survival. These data emphasise that combined analysis of the expression of all four EGF receptors provide more accurate information on the tumour behaviour than analysis of the expression of the individual receptors. Therefore, one possibility for the conflicting data on the consequences of high HER1 and HER2 expression in bladder cancer patients published until now could be related to the function of HER3 or HER4 expression, which was ignored in most of the studies.

In conclusion, our results suggest that expression of different combinations of receptor can change the final outcome of the disease, and we suggest that the expression of HER3 and HER4 should be taken into account for future evaluation of the consequences of HER1 and HER2 expression in bladder cancer. This might also be of importance in identifying patients, which may benefit from the specific antitumoural drugs designed to target the EGF receptors.

\section{ACKNOWLEDGEMENTS}

We thank Alice Villemoes, Marianne Lysdahl, Hanne Steen and Birgit Mortensen of the University Hospital of Aarhus for excellent technical assistance. This work was supported by the Danish Medical Research Council, the Danish Cancer Society and the Clinical Research Unit of the Danish Cancer Society, Aarhus.

\section{REFERENCES}

Abd El-Rehim DM, Pinder SE, Paish CE, Bell JA, Rampaul RS, Blamey RW, Robertson JF, Nicholson RI, Ellis IO (2004) Expression and coexpression of the members of the epidermal growth factor receptor (EGFR) family in invasive breast carcinoma. Br J Cancer 91: 1532-1542
Agudo D, Gomez-Esquer F, Martinez-Arribas F, Nunez-Villar MJ, Pollan M, Schneider J (2004) Nup88 mRNA overexpression is associated with high aggressiveness of breast cancer. Int J Cancer 109: $717-720$ 
Andersson U, Guo D, Malmer B, Bergenheim AT, Brannstrom T, Hedman $\mathrm{H}$, Henriksson R (2004) Epidermal growth factor receptor family (EGFR, ErbB2-4) in gliomas and meningiomas. Acta Neuropathol (Berlin) 108: $135-142$

Arpino G, Green SJ, Allred DC, Lew D, Martino S, Osborne CK, Elledge RM (2004) HER-2 amplification, HER-1 expression, and tamoxifen response in estrogen receptor-positive metastatic breast cancer: a southwest oncology group study. Clin Cancer Res 10: $5670-5676$

Barnes NLP, Khavari S, Boland GP, Cramer A, Knox WF, Bundred NJ (2005) Absence of HER4 expression predicts recurrence of ductal carcinoma in situ of the breast. Clin Cancer Res 11: 2163-2168

Bergkvist A, Ljungqvist A, Moberger G (1965) Classification of bladder tumours based on the cellular pattern. Preliminary report of a clinicalpathological study of 300 cases with a minimum follow-up of eight years. Acta Chir Scand 130: 371-378

Blackwell KL, Dewhirst MW, Liotcheva V, Snyder S, Broadwater G, Bentley R, Lal A, Riggins G, Anderson S, Vredenburgh J, Proia A, Harris LN (2004) HER-2 gene amplification correlates with higher levels of angiogenesis and lower levels of hypoxia in primary breast tumors. Clin Cancer Res 10: $4083-4088$

Burden S, Yarden Y (1997) Neuregulins and their receptors: a versatile signaling module in organogenesis and oncogenesis. Neuron 18: 847-855

Chakravarti A, Winter K, Wu CL, Kaufman D, Hammond E, Parliament M, Tester W, Hagan M, Grignon D, Heney N, Pollack A, Sandler H, Shipley W (2005) Expression of the epidermal growth factor receptor and Her-2 are predictors of favorable outcome and reduced complete response rates, respectively, in patients with muscle-invading bladder cancers treated by concurrent radiation and cisplatin-based chemotherapy: a report from the Radiation Therapy Oncology Group. Int J Radiat Oncol Biol Phys 62: 309-317

Chiu AW, Huang YL, Huan SK, Wang YC, Ju JP, Chen MF, Chou CK (2002) Potential molecular marker for detecting transitional cell carcinoma. Urology 60: $181-185$

Chomczynski P, Sacchi N (1987) Single-step method of RNA isolation by acid guanidinium thiocyanate phenol chloroform extraction. Anal Biochem 162: 156-159

Cohen BD, Kiener PA, Green JM, Foy L, Fell HP, Zhang K (1996) The relationship between human epidermal growth-like factor receptor expression and cellular transformation in NIH3T3 cells. I Biol Chem 271: $30897-30903$

Diermeier S, Horvath G, Knuechel-Clarke R, Hofstaedter F, Szollosi J, Brockhoff G (2005) Epidermal growth factor receptor coexpression modulates susceptibility to Herceptin in HER2/neu overexpressing breast cancer cells via specific erbB-receptor interaction and activation. Exp Cell Res 304: 604-619

Ekberg T, Nestor M, Engstrom M, Nordgren H, Wester K, Carlsson J, Anniko M (2005) Expression of EGFR, HER2, HER3, and HER4 in metastatic squamous cell carcinomas of the oral cavity and base of tongue. Int J Oncol 26: 1177-1185

Gandour-Edwards R, Lara Jr PN, Folkins AK, LaSalle JM, Beckett L, Li Y, Meyers FJ, DeVere-White R (2002) Does HER2/neu expression provide prognostic information in patients with advanced urothelial carcinoma? Cancer 95: 1009-1015

Garcia I, Vizoso F, Martin A, Sanz L, Abdel-Lah O, Raigoso P, GarciaMuniz JL (2003) Clinical significance of the epidermal growth factor receptor and HER2 receptor in resectable gastric cancer. Ann Surg Oncol 10: $234-241$

Guy PM, Platko JV, Cantley LC, Cerione RA, Carraway KL (1994) Insect Cell-Expressed P180(Erbb3) Possesses An Impaired Tyrosine KinaseActivity. Proc Natl Acad Sci USA 91: 8132-8136

Jimenez RE, Hussain M, Bianco Jr FJ, Vaishampayan U, Tabazcka P, Sakr WA, Pontes JE, Wood Jr DP, Grignon DJ (2001) Her-2/neu overexpression in muscle-invasive urothelial carcinoma of the bladder: prognostic significance and comparative analysis in primary and metastatic tumors. Clin Cancer Res 7: 2440-2447

Junttila TT, Laato M, Vahlberg T, Soderstrom KO, Visakorpi T, Isola J, Elenius K (2003) Identification of patients with transitional cell carcinoma of the bladder overexpressing ErbB2, ErbB3, or specific ErbB4 isoforms: real-time reverse transcription-PCR analysis in estimation of ErbB receptor status from cancer patients. Clin Cancer Res 9: $5346-5357$

Knowlden JM, Gee JM, Seery LT, Farrow L, Gullick WJ, Ellis IO, Blamey RW, Robertson JF, Nicholson RI (1998) c-erbB3 and c-erbB4 expression is a feature of the endocrine responsive phenotype in clinical breast cancer. Oncogene 17: 1949-1957
Kruger S, Weitsch G, Buttner H, Matthiensen A, Bohmer T, Marquardt T, Sayk F, Feller AC, Bohle A (2002) HER2 overexpression in muscleinvasive urothelial carcinoma of the bladder: prognostic implications. Int J Cancer 102: $514-518$

Lonn U, Lonn S, Friberg S, Nilsson B, Silfversward C, Stenkvist B (1995) Prognostic value of amplification of c-erb-B2 in bladder carcinoma. Clin Cancer Res 1: 1189-1194

Mellon JK, Lunec J, Wright C, Horne CH, Kelly P, Neal DE (1996) C-erbB-2 in bladder cancer: molecular biology, correlation with epidermal growth factor receptors and prognostic value. J Urol 155: 321-326

Memon AA, Sorensen BS, Melgard P, Fokdal L, Thykjaer T, Nexo E (2004) Expression of HER3, HER4 and their ligand heregulin-4 is associated with better survival in bladder cancer patients. Br J Cancer 91: 2034-2041

Nielsen TO, Hsu FD, Jensen K, Cheang M, Karaca G, Hu Z, HernandezBoussard T, Livasy C, Cowan D, Dressler L, Akslen LA, Ragaz J, Gown AM, Gilks CB, van de RM, Perou CM (2004) Immunohistochemical and clinical characterization of the basal-like subtype of invasive breast carcinoma. Clin Cancer Res 10: 5367-5374

Olayioye MA, Neve RM, Lane HA, Hynes NE (2000) The ErbB signaling network: receptor heterodimerization in development and cancer. $E M B O$ J 19: $3159-3167$

Pinkas-Kramarski R, Soussan L, Waterman H, Levkowitz G, Alroy I, Klapper L, Lavi S, Seger R, Ratzkin BJ, Sela M, Yarden Y (1996) Diversification of Neu differentiation factor and epidermal growth factor signaling by combinatorial receptor interactions. EMBO J 15: 2452-2467

Popov Z, Gil-Diez-De-Medina S, Ravery V, Hoznek A, Bastuji-Garin S, Lefrere-Belda MA, Abbou CC, Chopin DK (2004) Prognostic value of EGF receptor and tumor cell proliferation in bladder cancer: therapeutic implications. Urol Oncol 22: 93-101

Quinn CM, Ostrowski JL, Lane SA, Loney DP, Teasdale J, Benson FA (1994) c-erbB-3 protein expression in human breast cancer: comparison with other tumour variables and survival. Histopathology 25: 247-252

Ravery V, Grignon D, Angulo J, Pontes E, Montie J, Crissman J, Chopin D (1997) Evaluation of epidermal growth factor receptor, transforming growth factor alpha, epidermal growth factor and c-erbB2 in the progression of invasive bladder cancer. Urol Res 25: 9-17

Rotterud R, Nesland JM, Berner A, Fossa SD (2005) Expression of the epidermal growth factor receptor family in normal and malignant urothelium. BJU Int 95: 1344-1350

Sartor CI, Zhou H, Kozlowska E, Guttridge K, Kawata E, Caskey L, Harrelson J, Hynes N, Ethier S, Calvo B, Earp HS (2001) HER4 mediates ligand-dependent antiproliferative and differentiation responses in human breast cancer cells. Mol Cell Biol 21: 4265-4275

Spiessl B., Beahrs O.H., Hermanek P., Hutter R.V.P., Scheibe O., Sobin L.H., Wagner G (2003) UICC. International Union Against Cancer. TNM Atlas. Illustrated Guide to the TNM/pTNM Classification of Malignant Tumours. 3rd ed. Springer-Verlag: Berlin

Suo Z, Risberg B, Kalsson MG, Willman K, Tierens A, Skovlund E, Nesland JM (2002) EGFR family expression in breast carcinomas. c-erbB-2 and cerbB-4 receptors have different effects on survival. J Pathol 196: 17-25

Thogersen VB, Sorensen BS, Poulsen SS, Orntoft TF, Wolf H, Nexo E (2001) A subclass of HER1 ligands is a prognostic marker for survival in bladder cancer patients. Cancer Res 61: 6227-6233

Thybusch-Bernhardt A, Beckmann S, Juhl H (2001) Comparative analysis of the EGF-receptor family in pancreatic cancer: expression of HER-4 correlates with a favourable tumor stage. Int J Surg Investig 2: 393-400

Tovey SM, Witton CJ, Bartlett JM, Stanton PD, Reeves JR, Cooke TG (2004) Outcome and human epidermal growth factor receptor (HER) 1-4 status in invasive breast carcinomas with proliferation indices evaluated by bromodeoxyuridine labelling. Breast Cancer Res 6: R246-R251

Tzahar E, Pinkas-Kramarski R, Moyer JD, Klapper LN, Alroy I, Levkowitz G, Shelly M, Henis S, Eisenstein M, Ratzkin BJ, Sela M, Andrews GC, Yarden Y (1997) Bivalence of EGF-like ligands drives the ErbB signaling network. EMBO J 16: $4938-4950$

Vageli D, Kiaris H, Delakas D, Anezinis P, Cranidis A, Spandidos DA (1996) Transcriptional activation of $\mathrm{H}$-ras, $\mathrm{K}$-ras and $\mathrm{N}$-ras proto-oncogenes in human bladder tumors. Cancer Lett 107: $241-247$

Walker RA, Dearing SJ (1999) Expression of epidermal growth factor receptor mRNA and protein in primary breast carcinomas. Breast Cancer Res Treat 53: 167-176

Witton CJ, Reeves JR, Going JJ, Cooke TG, Bartlett JM (2003) Expression of the HER 1-4 family of receptor tyrosine kinases in breast cancer. J Pathol 200: $290-297$

Yarden Y, Sliwkowski MX (2001) Untangling the ErbB signalling network. Nat Rev Mol Cell Biol 2: 127-137 